\title{
Work-Family Conflict and Worker's Performance during Covid-19 Pandemic: What is the Role of Readiness to Change Mentality?
}

\author{
Dewiana Novitasari ${ }^{1}$, Ipang Sasono ${ }^{2}$, Masduki Asbari ${ }^{3}$ \\ ${ }^{I}$ Sekolah TinggiIlmu EkonomiInsan Pembangunan, Kota Tangerang, Indonesia \\ ${ }^{2,3}$ STMIK Insan Pembangunan, Kota Tangerang, Indonesia
}

\begin{abstract}
This study aimed to measure the effect of work-family conflict on employee performance of the part-time employee of a packaging industry in Tangerang which are mediated by readiness for change. Data collection during covid-19 pandemic was done by simple random sampling technique and the returned and valid questionnaire results were 143 samples. Data processing was used SEM method with Smart PLS 3.0 software. The results of this study concluded that work-family conflict have negative and significant effect on the employee performance, but work-family conflict have a positive and significant effect on readiness for change. This study conclude also that readiness for change have a positive and significant effect on relationship workfamily conflict and employee performance. Readiness for change as fully mediator. This new research proposed a model for building employee performance among the part-time employee of a packaging industry in Tangerang through enhancing work-family conflict management practice with readiness for change as a mediator. This research could pave the way to improve employee readiness in facing the era of industrial revolution 4.0.
\end{abstract}

Keywords: Employee performance, readiness for change, work-family conflict.

\section{INTRODUCTION}

The pattern of productive family has been changing the pattern of traditional family as the model of the dominant family, thus causing the shifting of family models (Contzen\& Forney, 2017; Vrontis, Bresciani\&Giacosa, 2016; Anand \& Vohra, 2019; Barnett, Brennan \& Lee, 2018). Traditional family pattern is marked by the role of men as breadwinners and women as housewives. Traditionally, people judge that a woman should not get high education degrees because at the end woman would still be a housewife. Therefore, whenever a woman is trying to develop their talent by working, they would be judged by the society and would be considered as if they are putting aside their obligations as a housewife (Arifin, 2017; Sari, 2019).

As the times develop, the stigma that occurred in the society is starting to displaced by a modern consideration. By the presence of the similarity of rights between men and women in the society, plenty of women are starting to develop their talent by working outside the house (Nasir \&Lilianti, 2017). In this globalisation era, both women and men play double role as parents and breadwinners. There are many researches discussing workfamily conflict (WFC) on non-educational formal professional workers and studying WFC on the people that has teaching profession is still rare. In reality, WFC is occurred in every profession in this world, especially teachers and educators (Gu, You \& Wang, 2020). Greenhaus\&Beutell(1985) visualised the types of conflict related with the role of women in the house and workplace dilemma. Firstly, time-based conflict, which is the conflict that is occurred when the time that is able to be used to fulfil one role and the time that is unable to fulfil the other roles, cover time divisions, energy and possibilities between the role in work and household (Allen et al, 2019). Furthermore, strain based conflict, which refers to the appearance of tension and emotional condition that resulted by one of the roles that make a person is difficult to fulfil the demands of other roles. For example, a mother that is working from nine-to-five would surely feel tired and it would be difficult for them to sit down comfortably while spending time with their children and finish their housework. Moreover, behaviour based conflict, which is a conflict that appears when an expectation from a particular behaviour is different from the other behaviour expectations. The discrepancy of individual's behaviour in the workplace and inside the house 
that is affected by the difference in rules of career women's behaviour that is usually difficult to exchange roles between the ones that they carry out and other people's (Ohu et al, 2019).

As a wife, parent and employee at the same time may cause disharmony between one of the roles mentioned. One of the conflicts that appears related with multiple roles of women workers is work-family conflict. Work-family conflict is one of the form of interrole conflict, which is tension or role imbalance between roles that take place in workplace and household. (Kremer, 2016). High working hours and heavy workloads are a direct sign of a work-family conflict occurrence due to excessive time and effort used for working. This matter would result in lacking of time and energy that could be used to do family activities (Greenhaus\&Beutell,1985).

According to initial observation results, there are few conditions that could allow conflict to occur, the first thing is financial condition finansial (Odle-Dusseau, Matthews \& Wayne, 2018). Financial condition of the husband is unable to fulfil the needs in the family, thus they depend on their wives to help in meeting their financial needs (Kundu et al, 2016). Financial situation in this matter is not the only major element that triggers the occurrence of work-family conflict. There is another one factor that may result work-family conflict in an household, which is limited education factor (Jansen \&Hellsten, 2018). Most husbands or the patriarchs that have economic issues are only secondary high school graduates. With the such of degree of education, surely the ability of the husband to manage the conflict in the household is difficult, hence the miss understanding problems between the parents are often occur. The conflict that takes place from factors in the household would definitely affect the wife's career. Therefore, ability of the wife as an employee to build harmony between work and family is the major essential (Arslaner\&Boylu, 2017). The other factor that triggers the occurrence of workfamily conflict is the health of husband (Lambert et al, 2016). Health problem of the husband may cause inability of the husband to seek for an appropriate job. In fact, the husband may become as responsibility of the family.

Based on the description above, the author needs to do further research regarding work-family conflict of the women employees in Indonesia to investigate the conflict that would possibly happen between the family and work. Study for WFC has a significant value because they may reveal the relationship between work, household, health, and employee welfare.

\section{THEORETICAL STUDY AND HYPOTHESIS DEVELOPMENT}

\section{Work-family Conflict}

Definition of family has three point of views mentioned by Lestari(2012). The first is the definition of structural family, which defined based on the presence of family members, such as parents, children and other relatives. This definition is focusing on someone that becomes the part of the family. This perspective shows that family is the origin of a particular person (familiesoforigin), family as a source of new generations (familiesofprocreation), and extended family. Secondly, definition of functional family, which is defined by emphasis about the fulfilment of psychosocial assignments and functions. The function convers treatment, socialisation of children, emotional and material support, and fulfilment of certain roles. Moreover, definition of transactional family, which is defined as a group that develops intimacy through behaviours that creates identity as a family (family identity), could be in a form of emotional relationship, historical events, or even future goals. This perspective is focusing on how the family carries out the function.

According to Greenhaus\&Beutell(1985), work-family conflict is one of the forms of inter-role conflict, which is the pressure or imbalance of roles between work and family roles. High working hours and heavy workloads are a direct sign of a work-family conflict occurrence due to excessive time and effort used for working. This matter would result in lacking of time and energy that could be used to do family activities. Greenhaus\&Beutell (1985) visualised the types of conflict related with the role of women in the house and workplace dilemma. Firstly, time-based conflict, which is the conflict that is occurred when the time that is able to be used to fulfil one role and the time that is unable to fulfil the other roles, cover time divisions, energy and possibilities between the role in work and household. In this case, arranging schedules is a difficult thing and the time is very limited when demands and behaviour that are needed to portray do not correspond. The second is strain based conflict, which refers to the appearance of tension and emotional condition that resulted by one of the roles that make a person is difficult to fulfil the demands of other roles. For 
example, a mother that is working from nine-to-five would surely feel tired and it would be difficult for them to sit down comfortably while spending time with their children and finish their housework. The tension of this role may include stress, increase in blood pressure, anxiety, emotional condition and headaches. Thirdly, behaviour based conflict, which is a conflict that appears when an expectation from a particular behaviour is different from the other behaviour expectations. The discrepancy of individual's behaviour in the workplace and inside the house that is affected by the difference in rules of career women's behaviour that is usually difficult to exchange roles between the ones that they carry out and other people's(Asbari, Bernarto, et al., 2020; Asbari, Pramono, et al., 2020; Sutardi et al., 2020).

The problem that takes place between the two demands makes a particular person getting stressed in their personal life due to the imbalance between work and family. This condition needs a support from the company to sustain their personal life and career (Wu et al, 208). With the presence of support from the company towards the employee's personal life would improve their performance and work satisfaction of the employees towards the company.

\section{Readiness to Change}

Research done by (Holt et al., 2007) showed that readiness to change is a multidimension that is affected by worker's confidence that (a) they are able to implement changes that is proposed (which is change efficacy), (b) changes that are proposed is correspond to the organization (which is appropriateness), (c) leaders commit for changes that are proposed (which is management support), also (d) changes that are proposed should be beneficial for the members of organization (which is personal benefit). Still according to (Holt et al., 2007), the indicator that could be used to measure the readiness for change of the employees are:

1. Worker's confidence towards changes that are proposed is proper for the organization.

2. Worker's confidence towards organization would receive advantage from application of the changes.

3. Employees believe in the presence of logical reasons for changes and the presence of needs for the changes that are proposed.

4. Employees focus on the benefits of changes in the company.

5. Worker's confidence towards their capability to apply changes that are desired.

6. Worker's feeling towards leaders and management in the organization having commitments and supporting the implementation of changes that are desired.

7. Worker's feeling towards themselves that they would receive benefits from the implementation of changes that are desired.

To prepare employees to be confident enough to change in the organization, understanding the ways that could be used to grow readiness for change is necessary. There are two things that could be done by organization, which are establish readiness of the employees to change and solving problems of avoiding changes (Banjongprasert, 2017). (Hadiyani, 2014; Pramadani, 2012) claim that organizational commitment could affect the readiness to change. Organizational commitment is the desired to stay as a member of organization, trust and receiving values and organization's purpose as well as the willingness to work hard for the sake of organization's interest. Other than that, employee engagement (work involvement) has a role on the success of the implementation of organization's changes, especially in the larger scale, which involve every elements of the organization. Employees that are involved in the organizational activities will tend to support the journey of the changes of organization and ready to change(Novitasari, Asbari, et al., 2020; Novitasari, Sasono, et al., 2020).

\section{Worker's Performance}

Performance is the behaviour on how a target is achieved (Armstrong \& Taylor, 2014). Performance is the oriented process of the purpose that is directed to ensure that every organizational process is in the place to maximize the productivity of employees, team, and also the organization itself. In other opinion, performance is the things that are done or not done by the employees (Luthans, 2005). In order to find out the worker's performance in an organization, some certain aspects are needed. Performance is affected by variable that is related to work covering role-stress and work/non-work conflicts (Babin \& Boles, 1998). There are some 
criteria in measuring performance, which are quality, quantity, punctuality, cost effectiveness and interpersonal relationship (Bernardin \& Russel, 1993). Meanwhile, (Mathis \& Jackson, 2002) mentioned that worker's performance has some elements, namely quantity, quality, accuracy, attendance, cooperation, and loyalty.

\section{The Impact of Work-Family Conflict Towards Worker's Performance}

Research done by Gozukara and Colakoglu (2016) gave a result that there is no significant relationship between work-family conflict with the worker's performance. While research done by Goudarzi (2017) showed that work-family conflict has significant relationship with worker's performance, although the relationship is negative. That research showed the lack of work-family support, since it has major risk towards performance. This proves that work-family conflict has a significant relationship with performance (Geroda \& Puspitasari, 2017; Hsu, 2011). From all of the researches mentioned above, hence there is a hypothesis about the impact of work-family conflict variable towards worker's performance variable. Thus, based on the above justifications, the following hypothesis was developed and tested:

H1: work-family conflict has an impact towards performance

\section{The Impact of Work-Family Conflict Towards Readiness to Change}

There is not much of previous research that concludes that work-family conflict has significant impact towards readiness to change, as much as few other research discussing about this case (Braun \& Nieberle, 2017; Dai et al., 2016; Geroda \& Puspitasari, 2017; Mansour \& Tremblay, 2016; Netemeyer et al., 1996; Pluut et al., 2018). Therefore, author has made the second hypothesis below:

H2: Work-family conflict has significant impact towards readiness to change of the employees.

\section{Impact of Work-Family Conflict Towards Readiness to Change}

Holt,etal(2007) defined readiness as worker's trust that they are able to implement changes that are proposed (self-efficacy), these changes are appropriate for the organization (appropriateness), leaders commit in these changes (managementsupport), also these changes will give advantage to the members of the organization (personal benefit). From the explanation of Holt,etal(2007), an employee is declared as ready to change is when they show behaviour of acceptance, embracement, and adopt plans of changing that will be done. Before an employee is in a ready position, they should reflect content, context, process and individual attributes to perceive and believe the changes that will be done by the organization. Readiness to change has been an important factor in creating the success of changes (Armenakis et al., 1993). This is shown by the two behaviour when changes is done, which could be positive and negative. Positive behaviour is shown by the presence of readiness to change and the negative behaviour is shown by avoiding changes. Creating positive behaviour in employees could be done by building readiness to change in employees, so that the changes could achieve success that is desired.

H3: Readiness to change has an effect towards worker's performance.

\section{Impact of Work-Family Conflict Towards Worker's performance through Readiness to Change as a Mediator}

Some researchers concluded that work-family conflict has a significant relationship towards worker's performance variable through readiness to change (Katsaros et al., 2020). Partially, some other researchers mentioned the significant impact of work-family conflict towards readiness to change (Astuti \& Khoirunnisa, 2018; Sari, 2018), and there is a significant impact of readiness to change towards worker's performance (Fitriana \& Sugiyono, 2019). There is not much of research that gives a model of relationship of the readiness to change mediation variable towards the relationship between work-family conflict variable and worker's performance variable. Therefore, author has made the fourth hypothesis below:

H4: Work-family conflict has significant impact towards worker's performance through readiness to change as mediator. 


\section{RESEARCH METHOD}

\section{Definition of Operational Variable and Indicator}

Method that was used in this research is quantitative method. Data collection is done by spreading questionnaire to every employee working in packaging industry in Tangerang, Indonesia. Instrument that was used to measure the work-family conflict is adapted by (Netemeyer et al., 1996) using 5 items (WFC1-WFC5). Readiness to change is adapted by (Holt et al., 2007) using 7 items (RTC1-RTC7). Worker's performance is adapted by (Bernardin \& Russel, 1993) using 6 items (WP1-WP6). Research model can be seen in Figure 1. Questionnaire is closely designed except for questions/statements regarding respondent's identity, which is in a form of semiopened questionnaire. Every items of closed questions/statements were given five answer options, which are strongly agree (SA) 5 points, Agree (A) 4 points, neutral (N) 3 points, disagree (DA) 2 points, strongly disagree (SDA) 1 point. Method used in data preparation was by using PLS as well as software Smart PLS version 3.0 as the tool.

\section{Population and Sample}

Population in this research is the employee from one of the packaging industries in Tangerang, Indonesia, which has around 227 people. Questionnaire was spread by simple random sampling technique. Questionnaire results that were returned validly was 143 samples. So, the total sample was $71.11 \%$ from the whole population.

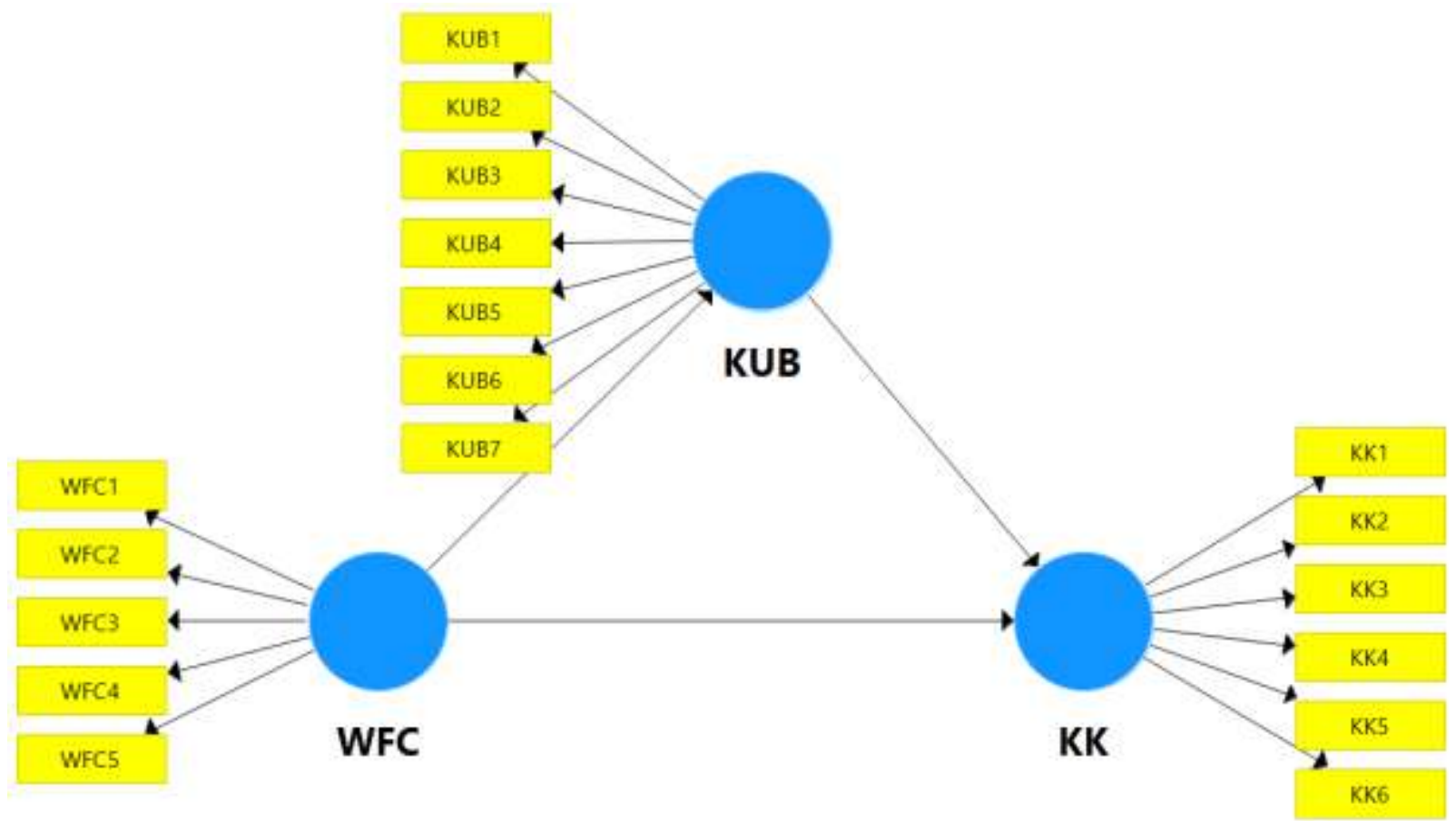




\section{RESEARCH RESULTS AND DISCUSSION Sample Description}

Table 1. Sample Description

\begin{tabular}{|c|c|c|c|}
\hline \multicolumn{2}{|c|}{ Criteria } & Total & $\%$ \\
\hline Age & $\begin{array}{l}<20 \text { years old } \\
20-30 \text { years old } \\
>30 \text { years old }\end{array}$ & $\begin{array}{l}36 \\
67 \\
40\end{array}$ & $\begin{array}{l}25.4 \% \\
46.6 \% \\
28.0 \%\end{array}$ \\
\hline Years of Service & $\begin{array}{l}<1 \text { year } \\
1-2 \text { years } \\
>3 \text { years }\end{array}$ & $\begin{array}{l}51 \\
69 \\
23\end{array}$ & $\begin{array}{l}35.7 \% \\
48.5 \% \\
15.8 \%\end{array}$ \\
\hline Last Education & $\begin{array}{l}\geq \text { Bachelor Degree } \\
\text { Senior High Sch. } \\
\text { Junior High Sch. }\end{array}$ & $\begin{array}{c}0 \\
125 \\
18\end{array}$ & $\begin{array}{c}0 \% \\
87.5 \% \\
12.5 \%\end{array}$ \\
\hline
\end{tabular}

\section{Validity Test Result and Research Reliability Indicator}

Stages on testing model of measuring involve convergent validity test and discriminant validity. While value of Cronbach's alpha and composite reliability are needed in testing for construction reliability. PLS analysis result could be used to test for research hypothesis if all indicators in PLS model has meet the requirements of convergent validity, discriminant validity and reliability test.

\section{Convergent Validity Testing}

Convergent validity test is done by seeing the value of loading factor of each indicators towards the construct. In most reference, with factor weighing from at least 0.5 is considered having validity that is strong enough to explain the latent construct (Chin, 1998; Ghozali, 2014; Hair et al., 2010). In this research, minimum limit of loading factor that is accepted is 0.5, with the condition of AVE score for every construct, which is $>0.5$ (Ghozali, 2014). After passing the process of Smart PLS 3.0, there are some indicators or items that needs to be taken out from the model. Furthermore, all indicators should have loading factor score above 0.5 or has meet the condition of AVE score above 0.5. Model that is fit and valid from the research could be seen on Figure 2. Therefore, convergent validity from this research model has meet all of the requirements. Loading score, Cronbach's alpha, composite reliability and AVE in every construct can be seen in Table 2 below: 


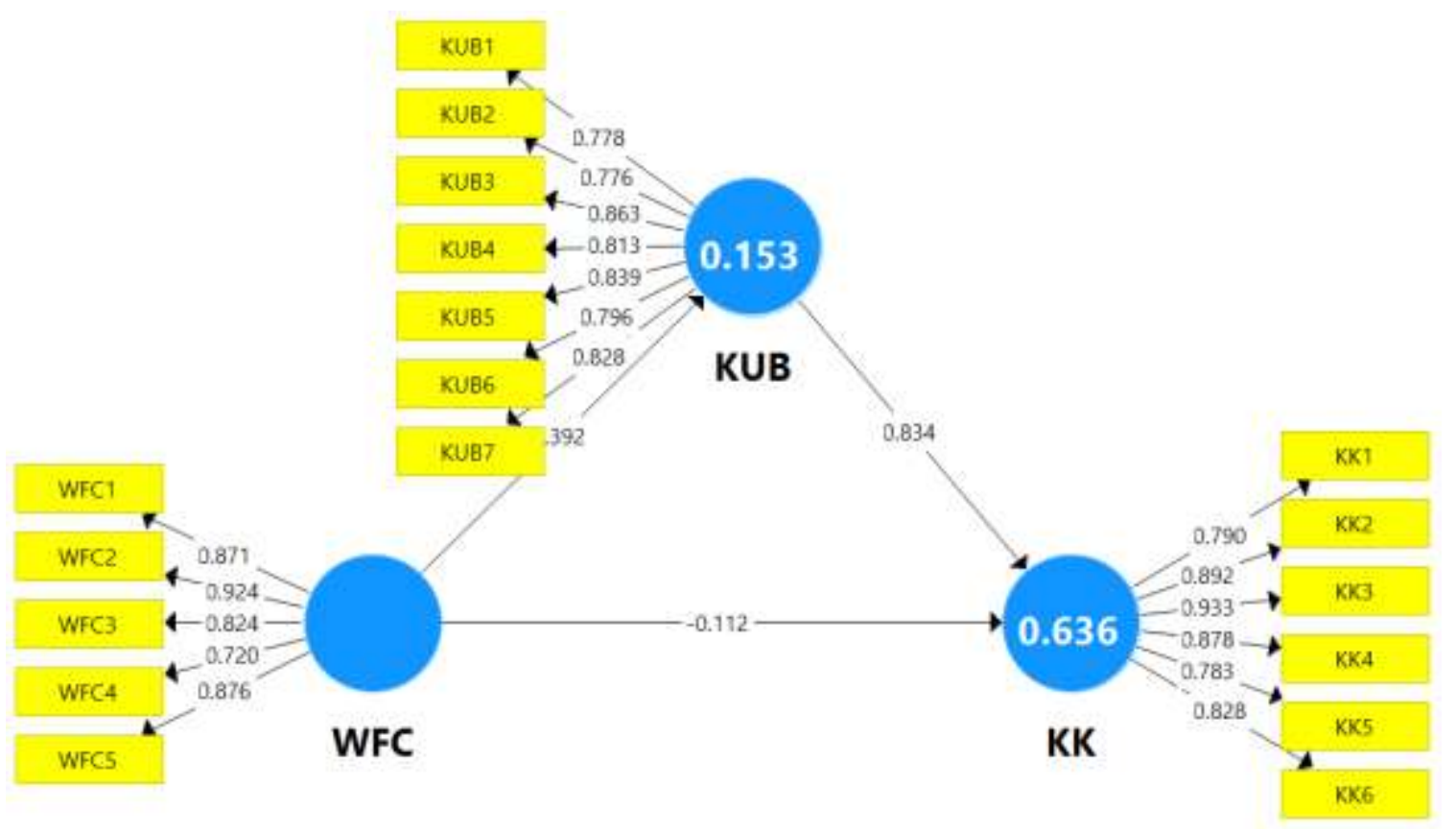

Figure 2. Valid Research Model

Tabel 2. Items Loadings, Cronbach's Alpha, Composite Reliability, and Average Variance Extracted

\begin{tabular}{llllll}
\hline Variables & Items & Loadings & $\begin{array}{l}\text { Cronbach's } \\
\text { Alpha }\end{array}$ & $\begin{array}{l}\text { Composite } \\
\text { Reliability }\end{array}$ & AVE \\
\hline Work-Family Conflict & WFC1 & 0.871 & 0.913 & 0.926 & 0.716 \\
(WFC) & WFC2 & 0.924 & & & \\
& WFC3 & 0.824 & & \\
& WFC4 & 0.720 & & 0.662 \\
& WFC5 & 0.876 & & 0.932 & \\
\hline Readiness to Change & RFC1 & 0.778 & 0.915 & & \\
(WFC) & RFC2 & 0.776 & & & \\
& RFC3 & 0.863 & & & \\
& RFC4 & 0.813 & & & \\
& RFC5 & 0.839 & & & \\
& RFC6 & 0.796 & & & \\
& RFC7 & 0.828 & & & \\
Worker's Performance & KK1 & 0.790 & 0.924 & & \\
& KK2 & 0.892 & & & \\
& KK3 & 0.933 & & & \\
& KK4 & 0.878 & & & \\
& KK5 & 0.783 & & & \\
& KK6 & 0.828 & & & \\
\end{tabular}

Table 3. Discriminant Validity

\begin{tabular}{lccc}
\hline \multicolumn{1}{c}{ Variables } & KK & KUB & WFC \\
\hline & & & \\
Worker's Performance (WP) & $\mathbf{0 . 8 5 2}$ & $\mathbf{0 . 8 1 4}$ & \\
Readiness to Change (RTC) & 0.790 & 0.392 & $\mathbf{0 . 8 4 6}$ \\
Work-Family Conflict (WFC) & 0.214 & & \\
\hline
\end{tabular}


Table 4. Collinearity Statistics (VIF)

\begin{tabular}{lll}
\hline \multicolumn{1}{c}{ Variables } & $\begin{array}{c}\text { Readiness to Change } \\
\text { (RTC) }\end{array}$ & $\begin{array}{c}\text { Worker's } \\
\text { Performance (WP) }\end{array}$ \\
\hline & & \\
Readiness to Change (RTC) & & 1.181 \\
Work-Family Conflict (WFC) & 1.000 & 1.181 \\
\hline
\end{tabular}

\section{Discriminant Validity Test}

Discriminant validity is done to ensure that every concept of each latent variables are in contrast with the other latent variables. A model has a good discriminant validity if the quadratic value of AVE in each exogeneous construct (value on the diagonal) exceeds the correlation between the construct with the other construct (value below diagonal) (Ghozali, 2014). Result of discriminant validity research is done by the quadratic value of AVE, which means by seeing the Fornell-Larcker Criterion Value that is obtained the same way as shown in Table 3.

Discriminant validity test result shown in Table 3 indicates the whole construct having square root value of AVE above correlation value with the other latent construct (through Fornell-Larcker Criterion) including crossloading value of the whole item from any indicator that is larger than the other indicator items as mentioned in Table 4, so it can be concluded that a model has meet a discriminant validity (Fornell\&Larcker, 1981).

Moreover, collinearity evaluation is done to discover whether there is a collinearity in the model. To find out about collinearity, VIF estimation from every construct is required. If the VIF score is higher than 5, then the model will show a collinearity (Hair et al., 2014). It is shown the same way as in Table 4, all VIF score that is less than 5 means that the model has no collinearity.

\section{Construct Reliability Test}

Construct reliability can be assessed from the value of Cronbach's alpha and composite reliability from each construct. Value of composite reliability and Cronbach's alpha is suggested to be more than 0.7 (Ghozali, 2014). Reliability test result in the Table 2 above shows that all construct has composite reliability value and Cronbach's alpha value higher than $0.7(>0.7)$. In conclusion, all construct has meet the reliability that is required.

\section{Hypothesis Examination}

Hypothesis test in PLS is also denoted as inner model test. This test covers significance test that has a direct and indirect impact as well as how large is the measurement of the exogenous variable impact towards the endogenous variable. To discover the effect of transformational leadership towards worker's performance is through readiness to change as a mediation variable that needs a direct and indirect impact test. Impact test is done by using T-Statistic test in an analysis model called Partial Least Squared (PLS) with the help of SmartPLS 3.0 software. With the bootstrapping technique, R square value and significance test value can be obtained as shown in Table 5 and Table 6 below:

Table 5. $R$ Square Value

\begin{tabular}{lcc}
\hline & R Square & R Square Adjusted \\
\hline Readiness to Change (RTC) & 0.153 & 0.148 \\
Worker's Performance (WP) & 0.636 & 0.631 \\
\hline
\end{tabular}


Table 6. Hypotheses Testing

\begin{tabular}{llccccc}
\hline $\begin{array}{l}\text { Hypoth } \\
\text { eses }\end{array}$ & Relationship & Beta & SE & T Statistics & P-Values & Decision \\
\hline H1 & WFC ->KK & -0.112 & 0.049 & 2.272 & 0.023 & Supported \\
& & & & & & \\
H2 & WFC ->KUB & 0.392 & 0.058 & 6.734 & 0.000 & Supported \\
& & & & & & \\
H3 & KUB ->KK & 0.834 & 0.054 & 15.323 & 0.000 & Supported \\
& & & & & & \\
H4 & WFC ->KUB ->KK & 0.327 & 0.054 & 6.043 & 0.000 & Supported
\end{tabular}

Based on the Table 5 above, $R$ Square value of Readiness To Change (RTC) is 0.153 , which mean the variable of Readiness To Change is able to be explained by the work-family conflict (WFC) variable in the percentage of $15.3 \%$, while the other has the percentage of $84.7 \%$ clarified by other variables that are not discussed in this research. $R$ Square value of Worker's Performance (WP) is 0.636 , which means this variable is able to be justified by the work-family conflict (WFC) and Readiness To Change (RTC) variables in the percentage of $63.6 \%$, while the rest has the percentage of $36.4 \%$ explained by the other variables that are not discussed in this research. Meanwhile, Table 6 shows T-Statistics and P-Values which indicate the effect of the variables mentioned above.

\section{Discussion}

According to the statistical calculation summarized in Table 6 above, can be concluded that work-family conflict has negative significant effect towards worker's performance in an industry. Proven in the T-Statistics value of 2.272, which is more than 1.96 and the $P$-values value of 0.023 , which is smaller than 0.05 . This means that the first hypothesis (H1) is accepted because this case is corresponding with the research result of (Asbari, Bernarto, et al., 2020; Asbari, Pramono, et al., 2020; Sutardi et al., 2020; Yuwono et al., 2020). Therefore, work-family conflict experienced by the employees is significantly affect the worker's performance.

Based on the statistical calculation summarized in Table 6 above, it can be concluded that work-family conflict has positive and significant effect towards readiness to change of the workers in an industry. This is proven by the $T$ Statistics value of 6.734, which is larger than 1.96 and P-Values value of 0.000 , which is less than 0.05 . This means that the third hypothesis $(\mathrm{H} 2)$ is accepted. The conclusion of this research supports the evidence found in the previous research by (Astuti \& Khoirunnisa, 2018; Fitriana \& Sugiyono, 2019; Mahessa \& NRH, 2016) that work-family conflict is significantly and positively affect readiness to change.

Based on the statistical calculation summarized in Table 6 above, it can be concluded that readiness to change has positive and significant effect towards worker's performance in an industry. This is proven by the T-Statistics value of 15.323, which is larger than 1.96 and P-Values value of 0.000 , which is less than 0.05 . This means that the third hypothesis (H3) is accepted. The conclusion of this research supports the evidence found in the previous research by (Banjongprasert, 2017; Katsaros et al., 2020), that readiness to change is significantly and positively affect performance.

Based on the statistical calculation summarized in Table 6 above, it can be concluded that readiness to change has positive and significant effect towards worker's performance through readiness to change of the workers in an industry. This is proven by the T-Statistics value of 6.043, which is larger than 1.96 and P-Values value of 0.000 , which is less than 0.05 . This means that the fourth hypothesis (H4) is accepted. The conclusion of this research supports the evidence found in the previous research of (Katsaros et al., 2020) who claimed that readiness to change could mediate the effect of leadership towards worker's performance. In this research, the role of readiness to change is called as partial mediation. 


\section{CONCLUSION AND SUGGESTION}

\section{Conclusion}

Based on the results of this research, it can be concluded that work-family conflict gives negative and significant affect towards the worker's performance in the packaging industry. This means that the higher the family conflict experienced by an employee; the lower the worker's performance would get. Nevertheless, the confidence and spirit of the readiness to change in employees could improve their performance. The most interesting point of this research is during this Covid-19 pandemic, work-family conflict has highly significant effect towards worker's performance. On the other side, work-family conflict could also give positive and significant effect towards readiness to change of the employees in this Covid-19 pandemic. Why is that so? The answer is because during this pandemic era, the reality pushes the employees to accept the pandemic condition that does not only affect the country of Indonesia, but also worldwide. With this kind of awareness, the employees would try harder to survive and adapt to the changes due to Covid-19 pandemic. This research shows prove that readiness to change could be a full mediation towards the relationship between work-family conflict and worker's performance.

\section{Managerial Implications}

According to this research, it is suggested that the management division of packaging industry to maintain the management practices of work-family conflict in a form of coaching and counseling, especially by both the leaders or HRD team so it would not negatively affect the worker's performance. Moreover, the management should maintain the habit of providing a briefing and motivation to the leaders in the company to keep up with the readiness of change of the employees, especially during this Covid-19 pandemic. This is because readiness to change is the basic essential to start readiness to change of the employees to encounter the competition in this Industry 4.0 revolution era.

\section{Limitation}

This research has some limitations. Firstly, this research analyzes the effect of work-family conflict towards the worker's performance both directly and indirectly through the variable of readiness to change. This is because there would be a possibility of other variables, such as motivation, competency, management knowledge, organization's culture, etc. that would affect the worker's performance. The author highly recommends to look for, explore and analyze the next researches. Furthermore, this research is done in a manufacturing industry and would possibly not be generalized to other industries. Therefore, it is highly suggested to do a further research regarding this topic in other industries. It would also possibly to be added to the all regions, or even other countries, or would also be compared between small and medium-sized enterprises and big organizations.

\section{REFERENCES}

[1] Allen, A., Manning, W., Longmore, M. and Giordano, P. (2019). Young Adult Parents' Work-Family Conflict: The Roles of Parenting Stress and Parental Conflict. Blair, S. and Costa, R. (Ed.) Transitions into Parenthood: Examining the Complexities of Childrearing (Contemporary Perspectives in Family Research, Vol. 15), Emerald Publishing Limited, pp. 1-16. https://doi.org/10.1108/S1530-353520190000015001

[2] Anand, A. and Vohra, V. (2019). Alleviating employee work-family conflict: role of organizations. International Journal of Organizational Analysis, Vol. ahead-of-print No. ahead-of-print. https://doi.org/10.1108/IJOA-06-2019-1792

[3] Arifin, Zainul (2017). 'AisyiyahdanPembinaanPemberdayaanPerempuansebagaiUpayaMencapaiKesetaraan Gander. Forum IlmuSosial. 44(1): 68-71. doi: https://doi.org/10.15294/fis.v44i1.15548

[4] Armenakis, A. A., Harris, S. G., \&Mossholder, K. W. (1993). Creating Readiness for Organizational Change. Human Relations, 46(6), 681-703. https://doi.org/https://doi.org/10.1177/001872679304600601

[5] Armstrong, M., \& Taylor, S. (2014). Human Resource Management Practice. Ashford Colour Press Ltd.

[6] Arslaner, E. and Boylu, Y. (2017). Perceived organizational support, work-family/family-work conflict and presenteeism in hotel industry. Tourism Review, Vol. 72 No. 2, pp. 171-183. https://doi.org/10.1108/TR-09-2016-0031 
[7] Asbari, M., Bernarto, I., Pramono, R., Purwanto, A., Hidayat, D., Sopa, A., Alamsyah, V. U., Senjaya, P., Fayzhall, M., \&Mustofa. (2020). The effect of work-family conflict on job satisfaction and performance: A study of Indonesian female employees. International Journal of Advanced Science and Technology, 29(3), 6724-6748. http://sersc.org/journals/index.php/IJAST/article/view/7325

[8] Asbari, M., Pramono, R., Kotamena, F., Liem, J., Sihite, O. B., Alamsyah, V. U., Imelda, D., Setiawan, S. T., \&AgusPurwanto. (2020). StudiFenomenologi Work-Family Conflict DalamKehidupan Guru HonorerWanita. Edumaspul - JurnalPendidikan, 4(1), 180-201. https://doi.org/https://doi.org/10.33487/edumaspul.v4i1.347

[9] Astuti, E., \&Khoirunnisa, R. M. (2018). Pengaruh Employee Engagement, KomitmenOrganisasi, Dan KepemimpinanTransformasionalTerhadapKesiapanUntukBerubah (Readiness For Change) PadaKaryawanUniversitas Ahmad Dahlan. JURNAL FOKUS, 8(1), 47-66.

[10] Babin, B. J., \& Boles, J. S. (1998). Employee behavior in a service environment: A model and test of potential differences between men and women. Journal of Marketing, 62(2), 77-91. https://doi.org/10.2307/1252162

[11] Banjongprasert, J. (2017). An Assessment of Change-Readiness Capabilities and Service Innovation Readiness and Innovation Performance $\square$ : Empirical Evidence from MICE Venues. IJEM International Journal of Economics and Management, 11, 1-17.

[12] Barnett, R. C., Brennan, R. T., \& Lee, S. (2018). The work-family interface. In C. B Travis, J. W. White, A. Rutherford, W. S. Williams, S. L. Cook, \& K. F. Wyche (Eds.), APA handbooks in psychology®. APA handbook of the psychology of women: Perspectives on women's private and public lives (p. 425-442). American Psychological Association. https://doi.org/10.1037/0000060-023

[13] Bernardin, H., \&Russel, J. (1993). Human Resource Management: An Experimental Approach. McGraw Hill Companies.

[14] Braun, S., \&Nieberle, K. W. A. M. (2017). Authentic leadership extends beyond work: A multilevel model of work-family conflict and enrichment. Leadership Quarterly, 28(6), 780-797. https://doi.org/10.1016/j.leaqua.2017.04.003

[15] Chin, W. (1998). The Partial Least Squares Approach to Structural Equation Modeling (E. Modern Methods for Business Research, In: G. A. Marcoulides (ed.)). Lawrence Erlbaum Associates Publisher.

[16] Contzen, S., Forney, J. (2017). Family farming and gendered division of labour on the move: a typology of farming-family configurations. Agric Hum Values34:27-40. https://doi.org/10.1007/s10460-016-9687-2

[17] Dai, Y. De, Chen, K. Y., \&Zhuang, W. L. (2016). Moderating effect of work-family conflict on the relationship between leadermember exchange and relative deprivation: Links to behavioral outcomes. Tourism Management, 54, 369-382. https://doi.org/10.1016/j.tourman.2015.12.005

[18] Fitriana, R., \&Sugiyono. (2019). Kesiapanberubahpadasekretariatjenderalkementeriankelautandanperikananrepublikindonesia. IKRAITH EKONOMIKA VOL, 2(2), 42-51.

[19] Geroda, M. K. B., \&Puspitasari, E. (2017). THE IMPACT OF WORK-FAMILY CONFLICT TOWARD JOB PERFORMANCE THE CASE OF EXTERNAL AUDITOR. Parahyangan International 3th Accounting \& Business Conference, 641-663. http://103.36.68.33/index.php/piabc/article/view/2490/2205

[20] Ghozali, I. (2014). Structural Equation Modeling, MetodeAlternatifdengan Partial Least Square (PLS) (4th ed.). BadanPenerbitUniversitasDiponegoro.

[21] Goudarzi, H. T. (2017). Investigating the Effect of Work-Family Conflict and Work-Family Support on Job Satisfaction and Job Performance of National Iranian Drilling Company Employees. Human Resource Management in Oil Industry. 9(33): 111-132 URL: http://iieshrm.ir/article-1-213-en.html

[22] Gozukara, I. and Colakoglu, N. (2016). The Mediating Effect of Work Family Conflict on the Relationship between Job Autonomy and Job Satisfaction. Procedia Social and Behacior Sciences. 253-266. doi:10.1016/j.sbspro.2016.07.136

[23] Greenhaus, J. H., \&Beutell, N. J. (1985). Sources of Conflict between Work and Family Roles. The Academy of Management Review. 10(1): 76. doi:10.2307/258214

[24] Gu, Y., You, X., \& Wang, R. (2020). Job demands and emotional labor as antecedents of female preschool teachers' work-to-family conflict: The moderating role of job resources. International Journal of Stress Management, 27(1), 23-34. https://doi.org/10.1037/str0000130

[25] Hadiyani, S. (2014). PerananKomitmenOrganisasidan Employee Engagement terhadapKesiapanKaryawanuntukBerubah. JURNAL PSIKOLOGI, 41(1), 17-33.

[26] Hair, J. F., Black, W. C., Babin, B. J., \& Anderson, R. E. (2010). Multivariate Data Analysis (7th ed.). Pearson Prentice Hall.

[27] Hair, J. F., Hult, G. T., Ringle, C. M., \&Sarstedt, M. (2014). A primer partial least squaresstructural equation modeling (PLS-SEM). SAGE Publications. 
[28] Holt, D. T., Armenakis, A. A., Feild, H. S., \& Harris, S. G. (2007). Readiness for Organizational Change: The Systematic Development of a Scale. The Journal of Applied Behavioral Science, 43(2), 232-255. https://doi.org/10.1177/0021886306295295

[29] Hsu, Y. R. (2011). Work-family conflict and job satisfaction in stressful working environments: The moderating roles of perceived supervisor support and internal locus of control. International Journal of Manpower, 32(2), 233-248. https://doi.org/10.1108/01437721111130224

[30] Janzen, B., Hellsten, L.M. (2018). Does the psychosocial quality of unpaid family work contribute to educational disparities in mental health among employed partnered mothers?.Int Arch Occup Environ Health91,633-641. https://doi.org/10.1007/s00420-0181310-y

[31] Katsaros, K. K., Tsirikas, A. N., \&Kosta, G. C. (2020). The impact of leadership on firm financial performance: the mediating role of employees' readiness to change. Leadership \& Organization Development Journal, 41(3), 333-347. https://doi.org/https://doi.org/10.1108/LODJ-02-2019-0088

[32] Kremer, I. (2016). The relationship between school-work-family-conflict, subjective stress, and burnout", Journal of Managerial Psychology, Vol. 31 No. 4, pp. 805-819. https://doi.org/10.1108/JMP-01-2015-0014

[33] Kundu, S., Phogat, R., Datta, S. and Gahlawat, N. (2016). Impact of workplace characteristics on work-family conflict of dualcareer couples", International Journal of Organizational Analysis, Vol. 24 No. 5, pp. 883-907. https://doi.org/10.1108/IJOA-012015-0840

[34] Lambert, E. G., Qureshi, H., Frank, J., Keena, L. D., \& Hogan, N. L. (2016). The relationship of work-family conflict with job stress among Indian police officers: a research note. Police Practice and Research, 18(1), 37-48. doi:10.1080/15614263.2016.1210010

[35] Lestari, Sri. 2012. PsikologiKeluargaPenanamanNilaiDan PenangananKonflikDalamKeluarga.KencanaPerdanaMediaGroup

[36] Luthans, F. (2005). PerilakuOrganisasi (11th ed.). Penerbit ANDI.

[37] Mahessa, N. F., \& NRH, F. (2016). Gaya KepemimpinanMelayanidanKesiapanuntukBerubahpadaKaryawan BPJS Ketenagakerjaan. JurnalEmpati, 5(1), 113-116.

[38] Mansour, S., \& Tremblay, D.-G. (2016). Workload, generic and work-family specific social supports and job stress: mediating role of work-family and family-work conflict. International Journal of Contemporary Hospitality Management, 28(8). https://doi.org/http://dx.doi.org/10.1108/IJCHM-11-2014-0607

[39] Mathis, \& Jackson. (2002). ManajemenSumberDayaManusia (Pertama). SalembaEmpat.

[40] Nasir danLilianti (2017). PersamaanHak: PartisipasiWanitadalamPendidikan. Didaktis: JurnalPendidikandanIlmuPengetahuan. 17(1): 36-46. DOI: http://dx.doi.org/10.30651/didaktis.v17i1.1554

[41] Netemeyer, R. G., Boles, J. S., \&McMurrian, R. (1996). Development and validation of work-family conflict and family-work conflict scales. Journal of Applied Psychology, 81(4), 400-410. https://doi.org/10.1037/0021-9010.81.4.400

[42] Novitasari, D., Asbari, M., Sutardi, D., GazalI, \&Silitonga, N. (2020). MempertahankanKinerjaKaryawan di MasaPandemi Covid19: AnalisisKesiapanuntukBerubahdanEfektivitasKepemimpinanTransformasional. Value: JurnalManajemen Dan Akuntansi, 15(2), 22-37. https://doi.org/https://doi.org/10.32534/jv.v15i2.1152

[43] Novitasari, D., Sasono, I., Santoso, J., Sudiyono, R. $\quad$ N., \&Asbari, $\quad$ M. (2020). PengaruhKesiapanuntukBerubahpadaKaryawanManufaktur: AnalisisPraktikKepemimpinan di MasaPandemi Covid-19. JUMBO (JurnalManajemen ,Bisnis Dan Organisasi ), 4(1), 175-188. https://doi.org/http://dx.doi.org/10.33772/jumbo.v4i1.13260

[44] Odle-Dusseau, H. N., Matthews, R. A., \& Wayne, J. H. (2018). Employees' financial insecurity and health: The underlying role of stress and work-family conflict appraisals. Journal of Occupational and Organizational Psychology, 91(3), 546-568. doi:10.1111/joop. 12216

[45] Ohu, E. A., Spitzmueller, C., Zhang, J., Thomas, C. L., Osezua, A., \& Yu, J. (2019). When work-family conflict hits home: Parental work-family conflict and child health. Journal of Occupational Health Psychology, $24(5)$, 590-601. https://doi.org/10.1037/ocp0000145

[46] Pluut, H., Ilies, R., Curşeu, P. L., \& Liu, Y. (2018). Social support at work and at home: Dual-buffering effects in the work-family conflict process. Organizational Behavior and Human Decision Processes, 146(April 2016$)$, 1-13. https://doi.org/10.1016/j.obhdp.2018.02.001

[47] Pramadani, A. B. (2012). HubunganantaraKomitmenOrganisasidenganKesiapanuntukBerubahpadaKaryawanDivisi Enterprise Service (DES) Telkom Ketintang Surabaya. JurnalPsikologiIndustri Dan Organisasi, 1(03), 112-119.

[48] Sari, N.I. (2019). PerananPoetriMardikaDalamMendukungPendidikanPerempuanPribumiJawa 1912-1918. AVATARA, e-Journal PendidikanSejarah. 7(1). https://jurnalmahasiswa.unesa.ac.id/index.php/avatara/article/view/26579 
[49] Sari, P. O. (2018). Pengaruh Gaya KepemimpinanTransformasional, KomitmenAfektif, KomitmenKontinuansdanKomitmenNormatifterhadapKesiapanBerubah (StudiPada Bank BRI Kantor Wilayah Yogyakarta). EXERO $\square$ : Journal of Research in Business and Economics, 1(1), 68-89. https://doi.org/10.24071/exero.2018.010104

[50] Sutardi, D., Novitasari, D., Asbari, M., Silitonga, N., Nugroho, Y. A., Hutagalung, D., Mustofa, Chidir, G., Basuki, S., \&Yuwono, T. (2020). Pengaruh Work-Family Conflict, StresKerjadan Social Support terhadapKepuasanKerja: StudiKasuspada Guru Wanita di Tangerang. EduPsyCouns: Journal of Education, Psychology and Counseling, 2(1), 482-498. https://ummaspul.ejournal.id/Edupsycouns/article/view/513

[51] Vrontis, D., Bresciani, S. and Giacosa, E. (2016). Tradition and innovation in Italian wine family businesses", British Food Journal, Vol. 118 No. 8, pp. 1883-1897. https://doi.org/10.1108/BFJ-05-2016-0192

[52] Wu, G., Wu, Y., Li, H., \& Dan, C. (2018). Job Burnout, Work-Family Conflict and Project Performance for Construction Professionals: The Moderating Role of Organizational Support. International Journal of Environmental Research and Public Health, 15(12), 2869. doi:10.3390/ijerph15122869

[53] Yuwono, T., Novitasari, D., Asbari, M., Sutardi, D., Mustofa, \&Asbari, M. (2020). Peran Organizational Commitment terhadapHubungan Work- Family Conflict danKepuasanKerjaKaryawanWanita di Kota SeribuIndustriTangerang. EduPsyCouns: Journal of Education, Psychology and Counseling, 2(1), 524-540. https://ummaspul.e-journal.id/Edupsycouns/article/view/526/303 